University of Michigan Law School

University of Michigan Law School Scholarship Repository

\title{
Should I Stay or Should I Go? The Gender Gap for Securities and Exchange Commission Attorneys
}

\author{
Stephen J. Choi II \\ New York University School of Law \\ Mitu Gulati \\ Duke University School of Law \\ Adam C. Pritchard \\ University of Michigan Law School, acplaw@umich.edu
}

Available at: https://repository.law.umich.edu/articles/2236

Follow this and additional works at: https://repository.law.umich.edu/articles

Part of the Law and Gender Commons, Law and Society Commons, and the Legal Profession Commons

\section{Recommended Citation}

Choi, Stephen J., Mitu Gulati, and Adam C. Pritchard. "Should I Stay or Should I Go? The Gender Gap for Securities and Exchange Commission Attorneys." Journal of Law and Economics 62, no. 3 (2019): 427-456.

This Article is brought to you for free and open access by the Faculty Scholarship at University of Michigan Law School Scholarship Repository. It has been accepted for inclusion in Articles by an authorized administrator of University of Michigan Law School Scholarship Repository. For more information, please contact mlaw.repository@umich.edu. 


\title{
Should I Stay or Should I Go? The Gender Gap for Securities and Exchange Commission Attorneys
}

\author{
Stephen J. Choi New York University \\ Mitu Gulati Duke University
}

A. C. Pritchard University of Michigan

\begin{abstract}
Most research on the gender gap in the legal profession focuses on the private sector. We look at the gender gap in a setting where one might expect the gaps to be smaller: the Division of Enforcement of the Securities and Exchange Commission (SEC), which has a reputation for providing employees with good childcare and work flexibility. We find a substantial gender gap in assignments but only a modest one in pay. Men are also more likely to move laterally and more likely to move to lucrative private-sector jobs. What causes these gaps? The primary explanation for the gender gap from the extant literature is the gender differential in childcare. We do not find substantial evidence that having children affects pay and assignments at the SEC. The presence of children, however, does seem to affect the behavior of men and women differently in deciding when to leave the SEC.
\end{abstract}

\section{Introduction}

Gender gaps in wages, promotions, and employment rates have been documented across a wide range of labor markets (Altonji and Blank 1999; Blau and

The authors owe special thanks to the roughly two dozen former and current Securities and Exchange Commission (SEC) lawyers who provided comments and context at various stages of this project. Thanks, for comments, are also owed to Rick Abel, Elizabeth Ananat, Katherine Bartlett, Elizabeth Chambliss, Guy-Uriel Charles, Dhammika Dharmapala, Ronit Dinovitzer, Jessica Erickson, Anna Gelpern, Tristin Green, Ben Grunwald, Jill Hasday, Rob Jackson, Kimberly Krawiec, Jena Martin, Un Kyung Park, David Rosenfeld, Hillary Sale, John Stark, Joyce Sterling, Linda Thomsen, Urska Velikonja, Teresa Verges, and Michele Vollmer. Thanks also go to participants at a seminar at the SEC; the Conference on Empirical Legal Studies; the Second Annual Workshop for Corporate and Securities Litigation (University of Richmond); the National Business Law Scholars Conference; the Center on Finance, Law, and Policy Blue Bag Lunch and the Law and Economics Workshop (University of Michigan); and the Law, Identity, and Politics Workshop (Duke University). Cornerstone Research provided data on SEC enforcement actions. Pritchard acknowledges support from the William Cook Endowment of the University of Michigan. The research was done under Institutional Review Board protocol number 2018-0424 (Duke University).

[Joumal of Law and Economics, vol. 62 (August 2019)]

(C) 2019 by The University of Chicago. All rights reserved. 0022-2186/2019/6203-0014\$10.00 
Kahn 2017). One of the most extensively studied is the market for elite privatesector lawyers (Gorman 2006; Sterling and Reichman 2013, 2016). What is clear from the literature is that gaps exist across the board and invariably go in one direction: women are paid and promoted less. Unpacking the causal dynamic for the gap, however, has proved difficult. That said, one of the primary explanations given for the deficit in the literature is the gender differential in care, and especially childcare, responsibilities (Kleven, Landais, and Søgaard 2018; Slaughter 2015; Plickert and Sterling 2017).

In this article, we attempt to add to the understanding of the gender gap in the legal profession, particularly as a function of differential family responsibilities, by approaching it from a different direction than most of the prior studies. Instead of looking at the elite private bar-where one might expect the willingness and ability to adjust for differentials in childcare responsibilities to be relatively low-we examine attorneys at the Division of Enforcement of the Securities and Exchange Commission (SEC), which has a reputation for allowing flexible work schedules and providing high-quality childcare.

Public-sector institutions such as the SEC, however, no matter how progressive and child friendly they might be, do not exist in a vacuum. One of the primary benefits of working at an elite public institution such as the SEC is that it provides a pathway to the elite private sector via the lateral market. For our purposes, the benefit of this public-private pipeline is that it allows us to examine how the outside market (one that the literature tells us to expect to be less woman friendly) interacts with the internal labor market of the SEC.

Research shows that gender gaps tend to be large in elite private-sector jobs for lawyers (Scharf, Liebenberg, and Amalfe 2014) but smaller in the public sector (Gregory and Borland 1999; Bolton and de Figueiredo 2017). Male and female securities lawyers, therefore, may weigh private-sector and government jobs differently. The strength of these preferences, however, may vary with family circumstances, including responsibility for children. Lawyers at elite government jobs often get experience, training, and publicity that they could not match in the private sector (see Wilkins [1999], which examines the paths taken by the first generation of African American partners at elite firms). By examining an elite government job that may afford women greater training opportunities than the equivalent private-sector job, and that also provides lateral employment possibilities into lucrative private-sector jobs, we hope to gain new insight into the dynamics of the gender gap.

Our sample consists of the attorneys in the SEC's Division of Enforcement in 2004; we follow their career trajectories through 2016. An advantage of studying this group of lawyers is the availability of data on their assignments; most studies of lawyers do not have access to these types of data. Azmat and Ferrer (2017), for example, use hours billed as a key measure of lawyers' performance. We are able to go beyond that by looking at the specific type of assignments the lawyers perform at the SEC. These data allow us to control for quality of work experience and how it influences gender gaps in lateral job opportunities. 
We find evidence of gender gaps at the SEC. Men, over time, get more complex, high-profile assignments that might attract the attention of future employers. We do not find such a gap in compensation. Men are paid more on average, but the gap is modest and is not statistically significant in our multivariate analysis. When we examine who moves laterally, we find that men are more likely to leave, and when they do, they are more likely to move to the private sector. Women are more likely to move to the public or nonprofit sector.

To identify the causal relationship between gender and these gaps, we look at two aspects of the family environment that may shed light on whether genderbased preferences and responsibilities relating to family influence the gender gap. The first is childcare obligations, which is the dominant explanation for the gender gap in the literature. The second is an event that might be expected to increase childcare responsibilities, that is, when a nonsibling adult who lives with the SEC attorney moves to a different address (typically but not necessarily divorce-a companion-separation event). We do not find evidence of a gender compensation gap with respect to childcare obligations but do find limited evidence that a companion-separation event corresponds with gender compensation gaps in the SEC. Child-related differentials also show up when we examine lateral departures from the SEC. In particular, women with children make different choices about whether and when to move laterally than their male peers.

We proceed as follows. Section 2 provides background and hypotheses. Section 3 describes our sample and empirical tests. Section 4 concludes.

\section{Background and Hypotheses}

\subsection{Gender Gaps in the Legal Profession}

Our focus in this article is on the gender gap in the legal profession. Women have been going to law school in large numbers for at least 2 decades (Commission on Women in the Profession 2006, 2018). Legal education occurs at the graduate level and requires substantial investment. Students who go to law school, and particularly those who follow that by seeking an elite government job, we assume, tend to be dedicated to their future careers as lawyers.

Despite numerical equality among law school graduates, gender gaps persist in the profession. Female lawyers make 85 percent of what male lawyers earn (Dinovitzer et al. 2009), a narrowing of a long-standing disparity (Hagan 1990). Gender gaps in pay appear to increase at more senior levels. ${ }^{1}$ Finding a differential in wages, however, does not establish discrimination if we do not have data on job performance; employees with similar jobs can perform quite differently (Azmat and Ferrer 2017). Furthermore, attrition rates among female lawyers, particularly at early stages of a career, are higher than those for men (Kay, Alarie, and Adjei

${ }^{1}$ After the JD (Dinovitzer et al. 2004, 2009), an examination of lawyers' careers, finds that gender gaps in salaries increase over time, from roughly $\$ 6,000$ initially to approximately $\$ 20,000$ after 7 years in practice. See Sterling and Reichman (2013). 
2016). But attrition rates alone do not tell us much unless we control for other explanations such as increased childcare responsibilities (Sommerlad 2016).

Scholars have posited the existence of structural discrimination (Sturm 2001; Wilkins and Gulati 1998; Chambliss 1997). Explicit gender animus is disfavored in settings such as high-level legal jobs. These institutions are not only subject to employment laws that prohibit discrimination but tend to be publicly committed to promoting gender equality. How do gender gaps arise in such a setting? One answer is that private firms, which must deal with competitive markets, may be unwilling or unable to expend resources to change structural features of the workplace (for example, long hours) that would allow employees who need more flexibility to succeed (Landers, Rebitzer, and Taylor 1996; Thornton 2016). These work characteristics may produce two tracks to advancement, with those constrained by the structural barriers ending up on the less demanding track.

In public employment, the commitment to equal treatment of workers is likely to be at least as strong as, if not stronger than, in the private sector. In addition, government decision makers, unconstrained by market forces, may be better placed to invest in overcoming structural barriers. Structural discrimination models suggest two distinct effects for employment as a government lawyer. On the one hand, because of perceived barriers in the private sector, female lawyers who seek fulfilling and challenging work lives should, other things equal, value government work more than their male counterparts. On the other hand, if women want private-sector positions but cannot access them through the traditional inside-the-firm pathways, government employment might provide an alternate route to an eventual high-level position in the private sector.

For lawyers in the federal government, one study finds that women report earning 6 percent less than men (Dinovitzer et al. 2009). Part of the gap may be explained by the fact that women employed as lawyers by the federal government report working fewer hours than their male counterparts. This could reflect either a choice by women to work fewer hours or supervisors giving them less substantive assignments (Sterling and Reichman 2016).

Given their commitment to nondiscrimination, we expect government institutions like the SEC to adopt procedures to ensure that male and female employees are treated equally in case assignments. It is possible, however, that despite a facial commitment to nondiscrimination, the work environment may result in differential case assignments for men and women. Alternatively, men and women may have different preferences with respect to work and family environments, and this difference may produce a gap in case assignments. Gender differences are likely to emerge, we conjecture, as women get married (or cohabitate with a nonsibling adult companion) and have children. These changes may lead women to reduce their hours, go part-time, or take temporary absences from the workforce. The career costs of these temporary or partial opt outs can be high. In this regard, professions may vary in terms of employees' substitutability. In pharmacy, for example, the jobs tend to be standardized, and pharmacists can step in for each other. This flexibility has been posited as a reason for why the gen- 
der gap among pharmacists has become relatively small (Goldin 2014). By contrast, a trial lawyer running a case-who develops an understanding of the facts and legal theories, attends all the hearings, runs the depositions, and formulates a strategy-cannot be easily replaced by another attorney. ${ }^{2}$ For high-level government lawyers, particularly those experienced enough to assume managerial responsibilities, there may be little flexibility for those with care responsibilities, which increases the gender gap. In addition, the perception that women are more likely to opt out of challenging work may lead supervisors to assign them fewer or less-challenging cases.

\subsection{Securities and Exchange Commission Background}

The SEC is an elite government agency. Its reputation, coupled with the private-sector employment opportunities available to lawyers with SEC experience, translates into strong demand for jobs in the SEC's Division of Enforcement. A lawyer seeking even an entry-level position typically needs several years of legal experience and strong academic credentials. Higher-level positions require more experience, with top-level positions commonly filled by lawyers with long experience in the division or by partners at white-shoe firms.

The division's reputation for effectiveness helps fuel the revolving door-lawyers involved in the highest-profile matters have a leg up in finding a privatesector job. Public-sector experience-particularly in an elite enforcement setting-can be a stepping stone to the private sector (deHaan et al. 2015; Boylan 2005; Boylan and Long 2005). Individuals may view time spent working in government as an investment in human capital (Sauer 1998), offering an opportunity to specialize (Dinovitzer et al. 2004). Experience at the SEC is a valuable credential, lending individuals credibility as white-collar defense attorneys, for conducting internal investigations, or for serving as legal advisors to firms in financial services regulated by the SEC and the Financial Industry Regulatory Authority.

The revolving door between government and the private sector creates another opportunity for the gender gap to manifest itself. Having children is more likely to depress women's income in the private sector than in government (Dixon and Seron 1995). This suggests that there may be greater barriers to women advancing in law firm tournaments than in government jobs (Sterling and Reichman 2016). Employees (former and current) at the SEC with whom we had informal discussions uniformly described the SEC as child friendly with flexible hours and quality childcare.

The gender gap may also manifest itself among those who stay at the SEC. Not everyone will succeed in translating their SEC experience into lucrative privatesector employment. Some attorneys stay at the SEC by choice, but others may

\footnotetext{
${ }^{2}$ For discussions of how the lack of flexibility in legal jobs has disadvantaged women (or how the requests for flexibility can stigmatize those who ask for them), see Gorman (2006) and Thornton (2016). A recent, and much-discussed, study of what is perhaps one of the most flexible jobs-being an Uber driver-suggests that the gender gap can persist even in highly flexible settings (Cook et al. 2018).
} 
stay because their available private-sector opportunities are less attractive than those available to their colleagues. This possibility suggests a reverse selection effect, with the top performers leaving for more lucrative opportunities and the less ambitious staying behind (Goddeeris 1988). It also suggests, to the extent that there are stronger biases against women in the private sector, that women might be disadvantaged in obtaining lucrative lateral opportunities. On the other hand, if women do not fare as well in the private sector because they are given less training, mentorship, and sponsorship at early stages, some might choose to overcome those obstacles by gaining experience in a government setting that is more committed to women's development.

\section{Data and Results}

\subsection{Sample}

Our sample consists of attorneys who worked in the SEC's Division of Enforcement in 2004; we obtained their names from the SEC's 2004 telephone directory. ${ }^{3}$ There are 542 attorneys in the sample. Variable definitions are in Appendix A, and the details of our data collection are in Appendix B.

We classify attorneys hierarchically. Our categories, measured in 2004, are staff attorney, which consists of attorneys employed at the SK-14 pay scale or below and considered the entry-level attorneys, and top manager, which consists of attorneys employed at the SK-17 pay scale or above and who typically have the title assistant director, assistant district administrator, assistant regional director, or higher. Staff attorney is an entry-level position requiring limited prior experience. These attorneys do the bulk of the investigative work of the division. Top managers have supervisory responsibilities, which means they typically appear in more cases than subordinates. They are also more likely to be in a position to be recognized by private-sector employers. The baseline for comparison is all attorneys in pay grades SK-15 and SK-16, which we term midlevel attorneys.

We also distinguish among SEC offices. We code attorneys as regional if they work in an office other than New York or Washington, DC, in 2004. Given the concentration of the financial services industry in New York and the concentration of the white-collar-defense bar in Washington, attorneys in those offices may have more private-sector options than attorneys working in regional offices such as Fort Worth. At the same time, the cost of living in Washington and New York may also drive an exodus from the SEC for those with opportunities, particularly for individuals with children leaving for college. Attorneys working in lower-cost cities may feel less financial pressure to leave the SEC.

We create an indicator variable to reflect work experience prior to coming to the SEC: NLJ 250 Prior Partner, which equals one if the attorney was a partner at one of the 250 largest law firms in the United States before coming to the SEC and zero otherwise. To control for prior government experience, we create the

\footnotetext{
${ }^{3}$ We were unable to find SEC telephone directories more recent than the 2004 edition.
} 
Table 1

Descriptive Statistics for Independent Variables

\begin{tabular}{lcccr}
\hline & $N$ & Mean & Median & SD \\
\hline Attorney level: & & & & \\
Age & 386 & 40.6 & 40.0 & 7.884 \\
NLJ 250 Prior Partner & 363 & .066 & 0 & .249 \\
Prior Government Attorney & 363 & .176 & 0 & .382 \\
Top Law School & 411 & .453 & 0 & .498 \\
Regional Office & 418 & .438 & 0 & .497 \\
Staff Attorney & 411 & .372 & 0 & .484 \\
Top Manager & 411 & .229 & 0 & .421 \\
Female & 418 & .304 & 0 & .460 \\
Short Term & 418 & .471 & 0 & .500 \\
Long Term & 418 & .127 & 0 & .333 \\
Close to Retire & 407 & .039 & 0 & .195 \\
Attorney-year level: & & & & \\
Companion Separate & 4,598 & .014 & 0 & .116 \\
Child at Home & 3,707 & .368 & 0 & .482 \\
Child 5 & 3,707 & .057 & 0 & .231 \\
Child 6-14 & 3,707 & .223 & 0 & .416 \\
Child 15-18 & 3,707 & .137 & 0 & .344 \\
Scienter Cases in Prior Year & 4,180 & .083 & 0 & .359 \\
\hline
\end{tabular}

Note. Attorney-level variables are measured in 2004.

indicator variable Prior Government Attorney. For educational background, we use the law school attended. We define Top Law School as the top 18 law schools as ranked by U.S. News and World Report in 1992.

We construct indicator variables relating to an attorney's tenure at the SEC. We classify attorneys who started at the SEC in 1990 or earlier with the variable Long Term (indicating 15 or more years of experience at the SEC as of the end of 2004). We classify attorneys who started in 2000 or later with the variable Short Term (corresponding to attorneys with 5 or fewer years of experience at the SEC as of the end of 2004). We use Short Term to examine the career patterns of the relatively recent hires at the SEC as of 2004. The baseline category (Medium Term) consists of attorneys who started at the SEC between 1991 and 1999.

Table 1 provides descriptive statistics on characteristics of the SEC enforcement attorneys measured at the beginning of the data set in 2004. The average age of the SEC attorneys at the beginning of 2004 was 40.6 years. Women were 30.4 percent of the sample. Nearly 4 percent of the attorneys were close to retirement age in 2004, defined as 55 or older in 2004 (which equates to over 65 by 2015). Attorneys in the short-term group make up 47.1 percent of the sample; 12.7 percent were long-term SEC attorneys. Only 6.6 percent of the SEC attorneys had been partners at large firms before joining the SEC. In contrast, 17.6 percent of the SEC attorneys had served as a government attorney prior to joining the SEC. Almost half (45.3 percent) attended a top law school. Attorneys who were employed in regional or district offices (other than New York or Washington, DC) 
in 2004 made up 43.8 percent of the sample. In terms of job titles, those who were staff attorneys in 2004 made up 37.2 percent of the sample. Top managers in 2004 made up 22.9 percent of the sample. With regard to variables relating to the family environment, 1.4 percent of the attorneys experienced a companionseparation event in any given year during our sample period. A little more than a third (36.8 percent) of the attorneys had a child at home in a given year during our sample period.

We also perform $t$-tests of the difference by gender of each attorney characteristic variable (except Female). Men, on average, were slightly older (41.0 years versus 39.6 at the beginning of 2004; difference significant at the 10 percent level, $p=.093$ ). The other $t$-tests were insignificant.

\subsection{Dependent Variables}

Our empirical tests examine gender gaps in three areas: assignments, compensation, and departures from the SEC. The last area is outside the control of the SEC but may be affected by attorneys' work experiences while at the agency.

\subsubsection{Case Assignments}

We first examine differences in case assignments. We use case assignments involving fraud allegations that require a showing of scienter as a proxy for quality of work experience at the SEC. The SEC has a range of violations that it can allege, including actions involving inaccurate disclosures that can be premised on negligence or strict liability, but these tend to reflect less harm to investors. Allegations of fraud requiring proof of scienter are challenging to bring because they are more complex, often resulting in contested litigation. These cases involve serious disclosure violations and the largest potential penalties. Consequently, scienter cases against public companies and subsidiaries are typically higher profile and attract press coverage. Overall, a higher number of scienter cases for an attorney suggests greater involvement in enforcing substantial fraud violations that are more likely to get attention from private-sector employers.

Cases involving fraud, however, are likely to be more contentious than cases alleging regulatory violations, so lawyers who are averse to conflict may avoid them. Note here that we know only the fact that attorneys are assigned to these more challenging cases. ${ }^{4}$ On the basis of our informal discussions with Division of Enforcement attorneys, we conjecture that attorneys perceived as high per-

\footnotetext{
${ }^{4}$ The charges filed are not known at the time of the initial assignment, and the severity of the offense is revealed only during the course of the investigation. In addition, the investigating attorney has room to lobby for more serious charges if he or she thinks they are warranted. The variable Scienter Cases is underinclusive in that it does not include investigations that do not lead to the filing of a complaint. We also do not track SEC attorneys' involvement in actions involving only private companies, individuals, or administrative proceedings. (Prior to 2010, the SEC did not regularly list the attorneys involved in SEC administrative proceedings.) It therefore excludes cases such as Ponzi schemes and pump-and-dump schemes, which primarily involve individual defendants. Those cases likely provide experience less relevant to elite private-sector employers.
} 
formers will be assigned to these more complex cases because bosses benefit from their subordinates winning difficult cases. It is also possible, however, that biases play a role in assignments. In addition, although many cases are assigned by higher-ups within the division, other assignments result from lower-level attorneys pursuing a lead.

We collect SEC civil cases involving scienter allegations against public companies and their subsidiaries from 2005 to 2015 and compute the number of cases alleging scienter in which an attorney was involved for each year in our data set (Scienter Cases). As an alternative measure, we look at the number of civil insider-trading cases against any defendant to which an attorney is assigned from 2005 to 2015 . Like scienter cases against public companies, insider-trading cases brought by the SEC can involve both publicity and high complexity. Insidertrading offenses require proof of a number of challenging elements, including scienter, because most cases allege violations of Rule 10b-5.

Men are involved in twice as many scienter cases each year compared with women (means of .130 and .065 , respectively; difference significant at the 1 percent level, $p=.000) .{ }^{5}$ The mean number of scienter cases is small but important for the reputation and career of an attorney given the high-profile nature of these cases. We find a similar disparity for insider-trading cases, with men involved in a mean of .303 insider-trading cases each year and women in a mean of .176 (difference significant at the 1 percent level, $p=.000$ ).

Figure 1 shows the gap between men and women with respect to the number of yearly scienter case assignments by age. ${ }^{6}$ Note from Figure 1 that men consistently receive more yearly scienter case assignments compared with women. This gap narrows for men and women in their early to mid-40s but then widens again past the mid-40s until age 60 and older. ${ }^{7}$

\subsubsection{Salary}

We look at the base salaries and bonuses for the attorneys in our sample (Total Compensation) for each year from 2004 to 2015 or until the last year the attorney was employed at the SEC. The mean total compensation is $\$ 179,700$ for men and $\$ 177,700$ for women. This $\$ 2,000$ difference in compensation per year is statistically significant at the 5 percent level $(p=.037)$ but represents little more than 1 percent of the total compensation. Figure 2 presents mean total compensation (equal to base salary plus bonus) and shows that men and women of similar ages at the SEC generally receive similar compensation. Men receive higher total com-

\footnotetext{
${ }^{5}$ For most attorneys, the number of scienter cases in any given year is zero (91 percent of the attorney-years in our data set). The next most frequent occurrence is one scienter case in a year ( 7 percent of the attorney-years). Multiple scienter cases occur in 2 percent of the attorney-years.

${ }^{6}$ Attorneys younger than 30 and older than 70 are excluded from Figure 1, as the small number of observations involved makes the presentation subject to outliers. Those attorneys are included in the statistical analysis that follows. To smooth out yearly variations, Figure 1 reflects the mean number of scienter cases per year in 5-year bins starting at age 30.

${ }^{7}$ We find a similar pattern for insider-trading cases, with the difference that the gap appears to narrow for men and women in their late 40 s instead of early to mid-40s and then widens after age 50 .
} 


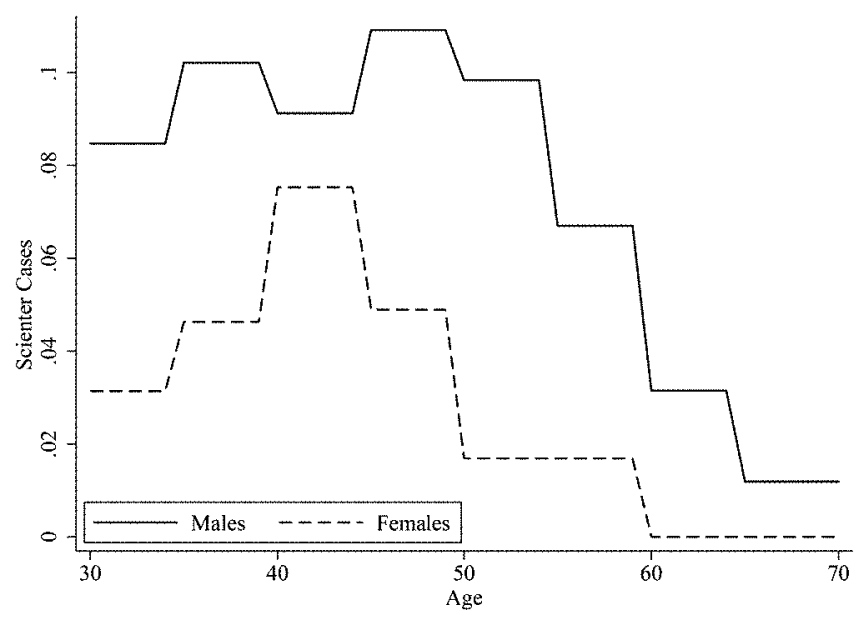

Figure 1. Yearly scienter case assignments

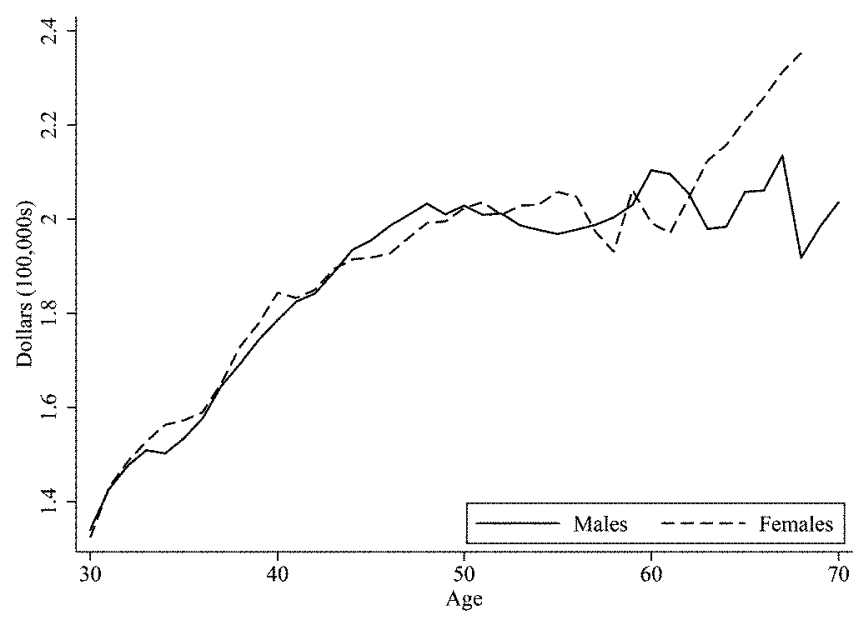

Figure 2. Mean total compensation

pensation from their mid-40s to around age 50, but women in their early $50 \mathrm{~s}$ to late 50 s earn more than men. In Appendix $C$ we construct an abnormal total compensation measure controlling for pre-SEC hiring characteristics of the attorneys. We observe a similar although not identical pattern for our measure of abnormal total compensation, with men receiving higher abnormal total compensation than women in their 40 s to early 50 s but with the gap narrowing in their mid- to late $50 \mathrm{~s}$. 


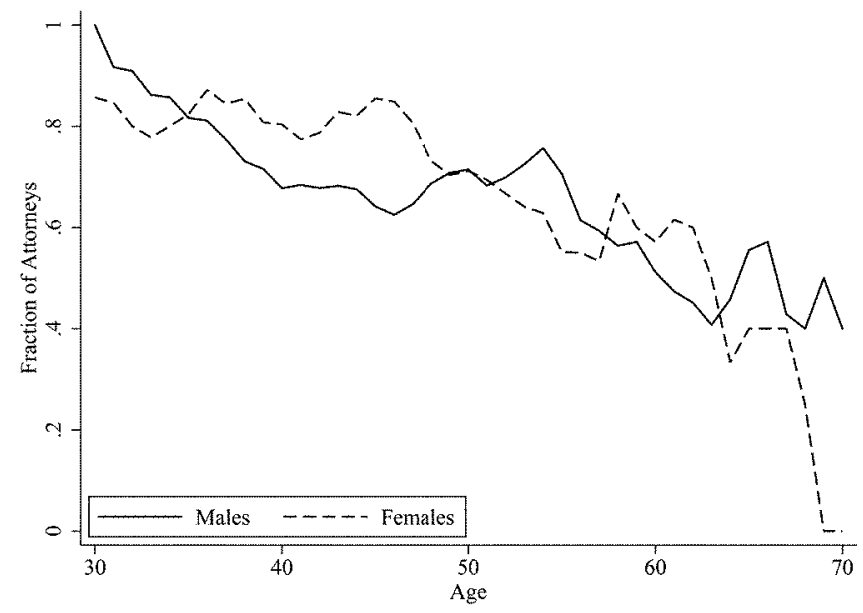

Figure 3. Attorneys employed at the Securities and Exchange Commission

\subsubsection{Lateral Moves}

Finally, we are interested in gender differences in departures from the Division of Enforcement. We define departure from the SEC as being no longer employed by the SEC in 2016. Male attorneys are more likely to exit than female attorneys. Of the attorneys in the sample in 2004, 58.8 percent of the men departed the SEC by 2016 , but only 40.9 percent of the women did (difference significant at the 1 percent level, $p=.001) .{ }^{8}$ Figure 3 shows the fraction of SEC attorneys by age in our data set who are still at the SEC. Figure 3 shows that women are more inclined to stay at the SEC until around age 50, possibly because of family considerations. We test the relation between the presence of children at home and the propensity to leave the SEC below. After age 50, as attorneys presumably come closer to the end of their careers, there is less of a clear pattern between men and women departing the SEC.

Figures 1-3 set forth the basic gender compensation and assignment gaps in the data for SEC enforcement attorneys. We move now to the multivariate analysis to investigate if we can explain the gaps in terms of observable features relating to family obligations.

\subsection{Case Assignments}

We begin our multivariate testing with case assignments. We estimate a regression model with Scienter Cases as the dependent variable using attorney-year

\footnotetext{
${ }^{8}$ We also examined the duration of employment at the SEC for the attorneys in our sample, defined as the number of years worked at the SEC up to and including 2016. For purposes of duration, we count a partial year as a full year at the SEC. Male attorneys have a shorter duration (15.7 years) compared with female attorneys ( 16.3 years), but the difference is not significantly different from 0 .
} 
data with year fixed effects and errors clustered by attorney. The base model (model 1) is

$$
\begin{aligned}
\text { Scienter Cases }_{i}= & \alpha+\beta_{1 i} \text { Age }_{i}+\beta_{2 i} \text { Age Squared }_{i}+\beta_{3 i} \text { NLJ } 250 \text { Prior Partner } \\
& +\beta_{4 i} \text { Prior Government Attorney }_{i}+\beta_{5 i} \text { Top Law School }_{i} \\
& +\beta_{6 i} \text { Regional Office }_{i}+\beta_{7 i} \text { Female }_{i}+\varepsilon_{i} .
\end{aligned}
$$

For independent variables, we include Age, Age Squared to control for nonlinearities in the relationship between age and Scienter Cases, and the following indicator variables: NLJ 250 Prior Partners, for attorneys who come to the agency with more experience; Prior Government Attorney, for attorneys who have relevant experience with enforcement work; Top Law School; Regional Office, to reflect a different mix of cases; and Female. We report the results for model 1 of Table 2.

In model 1 , the coefficient on Female is negative and significant at the 1 percent level. Women work on .064 fewer scienter cases than men each year. This is consistent with the summary statistic comparison of the mean scienter cases discussed above that indicates that men are assigned to approximately twice as many scienter cases as women. Looking at the control variables, we see that key variables point in predicted directions. Attorneys in regional offices have .060 fewer scienter cases per year (significant at the 1 percent level in model 1), which makes sense since the more complex and difficult cases are typically handled in New York and Washington. The magnitude of the negative relationship of Female on Scienter Cases in Prior Year and Regional Office on Scienter Cases in Prior Year are similar.

Returning to gender, to examine the correspondence between case assignments and tenure, we add to model 1 the indicator variables Short Term and Long Term and interaction terms Female $\times$ Short Term and Female $\times$ Long Term. (Medium Term is the base category in these models.) Time spent at the SEC may affect the expertise and strength of relationships enjoyed by an attorney at the SEC, which may affect case assignments. We report the results in model 2 of Table 2 . The coefficient on Female is negative and significant at the 1 percent level (as in model 1), which indicates that women receive fewer scienter case assignments than men. The coefficient on Female $\times$ Short Term is positive and significant at the 10 percent level, and the sum of Female and Female $\times$ Short Term, which represents the difference between men and women who are short-term employees, is negative and significant at the 10 percent level. The gap between men and women is smaller for short-term attorneys but still (weakly) statistically significant. The coefficient on Female $\times$ Long Term is positive and significant at the 10 percent level, and the sum of Female and Female $\times$ Long Term, which represents the difference between men and women who are long-term employees, is not significantly different from 0 . In effect, we find that the gender gap in assignments exists only marginally for the recent hires at the SEC and not at all for the veterans. Instead, the gender gap is largely driven by women in the middle to late-middle 
Table 2

Case Assignment Regression Models

\begin{tabular}{|c|c|c|c|c|c|}
\hline & (1) & (2) & (3) & (4) & (5) \\
\hline Age & $\begin{array}{l}.0243^{\star} \\
(2.31)\end{array}$ & $\begin{array}{l}.0173 \\
(1.61)\end{array}$ & $\begin{array}{c}.0134 \\
(1.37)\end{array}$ & $\begin{array}{l}.0177^{+} \\
(1.72)\end{array}$ & $\begin{array}{l}.0248^{\star} \\
(2.34)\end{array}$ \\
\hline Age Squared & $\begin{array}{l}-.0002^{\star} \\
(-2.29)\end{array}$ & $\begin{array}{l}-.0002 \\
(-1.60)\end{array}$ & $\begin{array}{l}-.0001 \\
(-1.35)\end{array}$ & $\begin{array}{l}-.0002^{+} \\
(-1.67)\end{array}$ & $\begin{array}{l}-.0003^{\star} \\
(-2.32)\end{array}$ \\
\hline NLJ 250 Prior Partner & $\begin{array}{l}.0665 \\
(1.08)\end{array}$ & $\begin{array}{l}.0693 \\
(1.11)\end{array}$ & $\begin{array}{l}.0501 \\
(.81)\end{array}$ & $\begin{array}{l}.0472 \\
(.77)\end{array}$ & $\begin{array}{c}.0661 \\
(1.07)\end{array}$ \\
\hline Prior Government Attorney & $\begin{array}{l}-.0057 \\
(-.21)\end{array}$ & $\begin{array}{l}-.0098 \\
(-.36)\end{array}$ & $\begin{array}{l}-.0126 \\
(-.47)\end{array}$ & $\begin{array}{l}-.0123 \\
(-.46)\end{array}$ & $\begin{array}{l}-.0064 \\
(-.23)\end{array}$ \\
\hline Top Law School & $\begin{array}{l}.0175 \\
(.85)\end{array}$ & $\begin{array}{l}.0177 \\
(.85)\end{array}$ & $\begin{array}{l}.0276 \\
(1.28)\end{array}$ & $\begin{array}{l}.0255 \\
(1.20)\end{array}$ & $\begin{array}{l}.0174 \\
(.85)\end{array}$ \\
\hline Regional Office & $\begin{array}{l}-.0603^{\star *} \\
(-2.90)\end{array}$ & $\begin{array}{l}-.0554^{* *} \\
(-2.64)\end{array}$ & $\begin{array}{l}-.0586^{\star *} \\
(-2.76)\end{array}$ & $\begin{array}{l}-.0538^{*} \\
(-2.52)\end{array}$ & $\begin{array}{l}-.0607^{* *} \\
(-2.92)\end{array}$ \\
\hline Female & $\begin{array}{l}-.0639^{\star \star} \\
(-3.56)\end{array}$ & $\begin{array}{l}-.116^{\star *} \\
(-3.56)\end{array}$ & $\begin{array}{l}-.0609^{\star \star} \\
(-3.35)\end{array}$ & $\begin{array}{l}-.0667^{\star \star} \\
(-3.72)\end{array}$ & $\begin{array}{l}-.0645^{\star \star} \\
(-3.56)\end{array}$ \\
\hline Short Term & & $\begin{array}{l}-.0582^{+} \\
(-1.67)\end{array}$ & & & \\
\hline Female $\times$ Short Term & & $\begin{array}{l}.0759^{+} \\
(1.88)\end{array}$ & & & \\
\hline Long Term & & $\begin{array}{l}-.0836^{+} \\
(-1.82)\end{array}$ & & & \\
\hline Female $\times$ Long Term & & $\begin{array}{c}.140^{+} \\
(1.93)\end{array}$ & & & \\
\hline Child at Home & & & $\begin{array}{l}.0357 \\
(1.10)\end{array}$ & & \\
\hline Female $\times$ Child at Home & & & $\begin{array}{l}.0191 \\
(.43)\end{array}$ & & \\
\hline Child $\leq 5$ & & & & $\begin{array}{l}.0141 \\
(.30)\end{array}$ & \\
\hline Female $\times$ Child $\leq 5$ & & & & $\begin{array}{l}.0755 \\
(1.28)\end{array}$ & \\
\hline Child 6-14 & & & & $\begin{array}{l}.0449 \\
(1.06)\end{array}$ & \\
\hline Female $\times$ Child $6-14$ & & & & $\begin{array}{l}-.0350 \\
(-.66)\end{array}$ & \\
\hline Child $15-18$ & & & & $\begin{array}{l}-.0542^{*} \\
(-2.09)\end{array}$ & \\
\hline Female $\times$ Child $15-18$ & & & & $\begin{array}{c}.123^{+} \\
(1.96)\end{array}$ & \\
\hline Companion Separate & & & & & $\begin{array}{l}-.0906 \\
(-1.50)\end{array}$ \\
\hline Female $\times$ Companion Separate & & & & & $\begin{array}{l}.0426 \\
(.62)\end{array}$ \\
\hline Constant & $\begin{array}{c}-.535^{\star} \\
(-2.13)\end{array}$ & $\begin{array}{r}-.327 \\
(-1.26)\end{array}$ & $\begin{array}{r}-.268 \\
(-1.13)\end{array}$ & $\begin{array}{r}-.373 \\
(-1.49)\end{array}$ & $\begin{array}{c}-.545^{\star} \\
(-2.17)\end{array}$ \\
\hline$N$ & 2,377 & 2,377 & 2,060 & 2,060 & 2,377 \\
\hline Adjusted $R^{2}$ & .040 & .043 & .037 & .037 & .040 \\
\hline
\end{tabular}

Note. Results are from regressions of Scienter Cases as the dependent variable on attorney-year data for each year an attorney is employed at the Securities and Exchange Commission (SEC) during the sample period; $t$-statistics are in parentheses. The attorney's last year at the SEC is excluded to control for possible departure midyear. All models control for year fixed effects and cluster errors by attorney.

$$
\begin{aligned}
& +p<.10 . \\
& { }^{*} p<.05 . \\
& { }^{* *} p<.01 .
\end{aligned}
$$


stages of their careers (similar to our finding in Figure 1), who appear to either receive or take on fewer complex assignments. ${ }^{9}$

Our results indicate that although women start out working on roughly the same mix of cases as men, gender gaps in assignments emerge as women reach the middle stages of their careers at the SEC. What explains the gap in case assignments? Is there something about the nature of challenging investigations that those lacking flexible schedules (that is, childcare responsibilities that are assumed to fall disproportionately on women) cannot take them on? As noted earlier, gender differences in childcare responsibilities are frequently cited as the key factor contributing to the gender gap (Kleven, Landais, and Søgaard 2018; Correll, Benard, and Paik 2007).

To disentangle the causal reason for this disparity, we look at two shifts in the family environment that may affect men and women differently. If women and men have different work-family preferences or responsibilities, a shift in an attorney's family situation should have a differential impact on men and women.

We first focus on whether the attorney lives in a household with a child who is 18 or younger (Child at Home) - roughly corresponding to precollege years-or in a household without such children. We conjecture that attorneys with children at home have greater household responsibilities. That in turn, other things equal, should affect job performance. In particular, if childcare responsibilities fall disproportionately on women, we should see the child penalty in the form of worse assignments also fall disproportionately on women.

We estimate difference-in-differences models of the difference between scienter cases assigned to men and women. For model 3 of Table 2, we add the indicator variable Child at Home and the interaction term Female $\times$ Child at Home to our base model.

The impact having of a child at home may vary according to the age of the child. For example, having pre-elementary-school children at home, who require greater care, may have a different effect on attorneys compared with having older children at home. To test this possibility, we create three additional indicator variables for whether in a particular year the attorney has a child between the ages of zero and five (Child $\leq 5$ ), six and 14 (Child 6-14), or 15 and 18 (Child 15-18). We reestimate model 3 , replacing Child at Home with Child $\leq 5$, Child

\footnotetext{
${ }^{9}$ As a robustness test (unreported), we added indicator variables for whether the SEC attorney is a staff attorney or top manager at the SEC to model 1 of Table 2. An attorney's position at the SEC may affect the number of scienter cases to which he or she is assigned irrespective of gender. Gender, however, may correlate with promotion to higher positions, such as top manager, so including those controls may bias against finding a gender effect. The coefficient on Staff Attorney is negative and significant at the 10 percent level, while the coefficient on Top Manager is positive and significant at the 1 percent level, consistent with our expectations. The coefficient on Female remains negative and significant at the 1 percent level. As an additional robustness test, we replaced the number of scienter cases for a given year with the number of insider-trading cases for a given year as the dependent variable in model 1 of Table 2. The coefficient on Female remains negative and significant at the 5 percent level in the model (unreported). Women receive fewer insider-trading case assignments compared with men.
} 
6-14, and Child 15-18 and interaction terms between these indicator variables and Female. We report the results in model 4 of Table 2.

Our second shift is separation from a companion (typically, divorce). We define Companion Separate as equal to one if the year or immediate prior year (a 2 -year window) is the last year in which the SEC attorney and companion share a household. Again, we conjecture that separation and the additional burdens that result from having two households will hurt job performance-and more so for women, under the assumption that they take the brunt of sudden unexpected increases in care responsibilities. To test this conjecture, we replace Child at Home and the interaction term Child at Home $\times$ Female in model 1 with an indicator variable for Companion Separate and the interaction term Female $\times$ Companion Separate that measures the difference in difference. We report the results in model 5 of Table 2 .

The coefficient on the interaction terms Female $\times$ Child at Home in model 3 and Female $\times$ Child $\leq 5$ and Female $\times$ Child $6-14$ in model 4 of Table 2 are not significantly different from 0 . The coefficient on Female $\times$ Child $15-18$ is positive in model 4 but significant only at the 10 percent level. Having a high-school-age child at home has a more positive impact on the number of scienter cases for women than men. The magnitude of Female $\times$ Child 15-18 is equal to .123 more scienter cases per year. While small, the magnitude is almost double the negative effect of Female alone (equal to .067 fewer scienter cases in model 4 ) and potentially important given the high-profile nature of scienter cases. The sum of Female and Female $\times$ Child $15-18$ is positive and not significantly different from 0 , which indicates that the differential between men and women in terms of scienter case assignments diminishes for attorneys with high-school-age children. ${ }^{10}$ Finally, the coefficient on Female $\times$ Companion Separate is not significantly different from 0 . We thus find mixed evidence that family-related factors explain the gender differences in scienter case assignments. Although there is limited evidence that the gender gap in case assignments diminishes for women with highschool-age children, we do not find any other evidence that family matters.

We also estimate attorney fixed-effects models to assess the impact of familyrelated shifts on individual attorneys, using the same variables as in models 3-5 of Table 2 (with the exception of Female), including year effects and clustering errors by attorney. The results (untabulated) are qualitatively similar to those for models 3-5 of Table 2, with the exception that Female $\times$ Child 15-18, while still positive, is not significantly different from 0 . That is, we do not find evidence that any of our family-related shifts result in a change in case assignments for either male or female attorneys in the attorney fixed-effects models.

\footnotetext{
${ }^{10}$ We created an indicator variable for whether the attorney has a child 19 or older (Child 19+). We reestimated model 4 of Table 2 with the addition of Child $19+$ and Female $\times$ Child 19+, treating attorneys with no children as the base category. We obtained the same qualitative results (unreported) as in model 4 with one difference: the coefficient on Female $\times$ Child $15-18$ is positive and significant at the 5 percent level instead of the 10 percent level. The coefficients on Child $19+$ and Female $\times$ Child $19+$ are not significantly different from 0 .
} 


\subsection{Compensation}

We next look at gender differences in compensation. We estimate a regression model with Total Compensation as the dependent variable using attorney-year data with year fixed effects and errors clustered by attorney. The base model (reported as model 1 of Table 3 ) is as follows:

$$
\begin{aligned}
\text { Total Compensation }_{i}= & \alpha+\beta_{1 i} \text { Age }+\beta_{2 i}{\text { Age Squared }+\beta_{3 i} \text { NLJ } 250 \text { Prior Partner }}_{i} \\
& +\beta_{4 i} \text { Prior Government Attorney }_{i}+\beta_{5 i} \text { Top Law School }_{i} \\
& +\beta_{6 i} \text { Regional Office }_{i}+\beta_{7 i} \text { Female }_{i}+\varepsilon_{i} .
\end{aligned}
$$

We include the independent variables Age, Age Squared, NLJ 250 Prior Partner, Prior Government Attorney, Top Law School, Regional Office, and Female to assess the relationship between the various attorney characteristic variables and pay at the SEC.

In model 1 of Table 3, the negative coefficient on Female corresponds to $\$ 2,170$ less in compensation per year for women compared with men. The coefficient on Female, however, is not significantly different from 0 . Moreover, $\$ 2,170$ is small in magnitude, representing a little over 1 percent of the mean total compensation for men and women. We find no evidence in our multivariate model that women receive appreciably lower pay than men at the SEC.

To assess whether fewer scienter case assignments in the prior year is related to lower salaries for women, we add Scienter Cases in Prior Year to model 1 and report the results in model 2 of Table 3. The coefficient on Scienter Cases in Prior Year is positive and significant at the 1 percent level, corresponding to $\$ 6,661$ higher total compensation for each scienter case in the prior year. As in model 1 , the coefficient on Female in model 2 is not significantly different from $0 .{ }^{11}$ After controlling for who is performing complex assignments, we are unable to reject the null hypothesis that female SEC attorneys are paid the same as men. ${ }^{12}$

To look at whether family shifts might correspond with gender-based differentials in compensation, we estimate a series of difference-in-differences models, adding additional variables to model 2 of Table 3 . In model 3 of Table 3 , we add the indicator variable Child at Home and the interaction term Female $\times$ Child at Home. In model 4 of Table 3, we add the indicator variables Child $\leq 5$, Child 6-14, and Child 15-18 and interaction terms between these variables and Female.

\footnotetext{
${ }^{11}$ We also performed a test of the null hypothesis that the coefficients on Female are equal in models 1 and 2 using seemingly unrelated estimation and were unable to reject the null hypothesis.

${ }^{12}$ As a robustness test (unreported), we added indicator variables for whether the SEC attorney is a staff attorney or top manager at the SEC to model 1 of Table 3. The coefficient on Staff Attorney is negative and significant at the 1 percent level, and the coefficient on Top Manager is positive and significant at the 1 percent level. The coefficient on Female remains not significantly different from 0 . As another robustness test, we replaced the number of scienter cases in the prior year with the number of insider-trading cases in the prior year in model 2 of Table 3 . The coefficient for the number of insider-trading cases in the prior year is positive and significant at the 1 percent level. As in the models of Table 3, the coefficient on Female remains not significantly different from 0.
} 
Table 3

Total-Compensation Regression Models

\begin{tabular}{|c|c|c|c|c|c|}
\hline & (1) & $(2)$ & (3) & (4) & (5) \\
\hline Age & $\begin{array}{l}.0730^{* *} \\
(7.46)\end{array}$ & $\begin{array}{l}.0719^{* *} \\
(6.83)\end{array}$ & $\begin{array}{l}.0669^{* *} \\
(6.50)\end{array}$ & $\begin{array}{l}.0667^{* *} \\
(6.44)\end{array}$ & $\begin{array}{l}.0733^{\star *} \\
(7.50)\end{array}$ \\
\hline Age Squared & $\begin{array}{l}-.0006^{* *} \\
(-6.37)\end{array}$ & $\begin{array}{l}-.0006^{* *} \\
(-5.87)\end{array}$ & $\begin{array}{l}-.0006^{\star *} \\
(-5.45)\end{array}$ & $\begin{array}{l}-.0006^{* *} \\
(-5.38)\end{array}$ & $\begin{array}{l}-.0007^{* *} \\
(-6.40)\end{array}$ \\
\hline NLJ 250 Prior Partner & $\begin{array}{l}-.0328 \\
(-.65)\end{array}$ & $\begin{array}{l}-.0457 \\
(-.87)\end{array}$ & $\begin{array}{l}-.0699 \\
(-1.63)\end{array}$ & $\begin{array}{l}-.0693^{+} \\
(-1.66)\end{array}$ & $\begin{array}{l}-.0305 \\
(-.61)\end{array}$ \\
\hline Prior Government Attorney & $\begin{array}{l}-.0211 \\
(-.75)\end{array}$ & $\begin{array}{l}-.0202 \\
(-.68)\end{array}$ & $\begin{array}{l}-.0237 \\
(-.83)\end{array}$ & $\begin{array}{l}-.0246 \\
(-.86)\end{array}$ & $\begin{array}{l}-.0219 \\
(-.77)\end{array}$ \\
\hline Top Law School & $\begin{array}{l}.0379+ \\
(1.88)\end{array}$ & $\begin{array}{l}.0353^{+} \\
(1.69)\end{array}$ & $\begin{array}{l}.0469^{\star} \\
(2.27)\end{array}$ & $\begin{array}{l}.0454^{*} \\
(2.20)\end{array}$ & $\begin{array}{l}.0384+ \\
(1.91)\end{array}$ \\
\hline Regional Office & $\begin{array}{l}.0529^{\star} \\
(2.48)\end{array}$ & $\begin{array}{l}.0569^{\star} \\
(2.56)\end{array}$ & $\begin{array}{l}.0425^{\star} \\
(2.02)\end{array}$ & $\begin{array}{l}.0439^{*} \\
(2.07)\end{array}$ & $\begin{array}{l}.0533^{*} \\
(2.51)\end{array}$ \\
\hline Female & $\begin{array}{l}-.0217 \\
(-.99)\end{array}$ & $\begin{array}{l}-.0202 \\
(-.89)\end{array}$ & $\begin{array}{l}-.0377 \\
(-1.40)\end{array}$ & $\begin{array}{l}-.0368 \\
(-1.41)\end{array}$ & $\begin{array}{l}-.0204 \\
(-.94)\end{array}$ \\
\hline Scienter Cases in Prior Year & & $\begin{array}{l}.0661^{\star *} \\
(6.24)\end{array}$ & & & \\
\hline Child at Home & & & $\begin{array}{l}.0478^{*} \\
(1.99)\end{array}$ & & \\
\hline Female $\times$ Child at Home & & & $\begin{array}{l}.0692^{+} \\
(1.73)\end{array}$ & & \\
\hline Child $\leq 5$ & & & & $\begin{array}{l}.0372 \\
(.89)\end{array}$ & \\
\hline Female $\times$ Child $\leq 5$ & & & & $\begin{array}{l}.0682 \\
(1.15)\end{array}$ & \\
\hline Child 6-14 & & & & $\begin{array}{l}.0539^{\star} \\
(2.45)\end{array}$ & \\
\hline Female $\times$ Child $6-14$ & & & & $\begin{array}{l}.0675^{+} \\
(1.92)\end{array}$ & \\
\hline Child 15-18 & & & & $\begin{array}{l}.0101 \\
(.38)\end{array}$ & \\
\hline Female $\times$ Child $15-18$ & & & & $\begin{array}{l}.0533 \\
(.97)\end{array}$ & \\
\hline Companion Separate & & & & & $\begin{array}{l}-.0538 \\
(-.83)\end{array}$ \\
\hline Female $\times$ Companion Separate & & & & & $\begin{array}{r}-.139 \\
(-1.61)\end{array}$ \\
\hline Constant & $\begin{array}{l}.219 \\
(.95)\end{array}$ & $\begin{array}{l}.239 \\
(.95)\end{array}$ & $\begin{array}{r}.328 \\
(1.35)\end{array}$ & $\begin{array}{r}.332 \\
(1.35)\end{array}$ & $\begin{array}{l}.212 \\
(.92)\end{array}$ \\
\hline$N$ & 2,387 & 2,080 & 2,074 & 2,074 & 2,387 \\
\hline Adjusted $R^{2}$ & .636 & .584 & .674 & .675 & .637 \\
\hline
\end{tabular}

Note. Results are from regressions of Total Compensation as the dependent variable on attorneyyear data; $t$-statistics are in parentheses. All models control for year fixed effects and cluster errors by attorney.

$$
\begin{aligned}
& +p<.10 . \\
& { }^{\star} p<.05 . \\
& { }^{*} p<.01 .
\end{aligned}
$$


In model 5 of Table 3, we add the indicator variable Companion Separate and the interaction term Female $\times$ Companion Separate.

In models 3-5 of Table 3, the coefficients on Female are negative but not significantly different from 0 . The coefficients on the presence of a child in two instances (Child at Home in model 3 and Child 6-14 in model 4) are positive and significant at the 5 percent level. The coefficient on Child at Home in model 3 corresponds to $\$ 4,780$ in additional annual compensation, and the coefficient on Child 6-14 in model 4 corresponds to $\$ 5,390$ in additional annual compensation. In those two models, the coefficients on Female $\times$ Child at Home and Female $\times$ Child 6-14 are also positive, and both are weakly significant at the 10 percent level. However, the sum of Female and Female $\times$ Child at Home and the sum of Female and Female $\times$ Child 6-14 are not significantly different from 0 . This indicates that, while having a child corresponds with higher compensation at the SEC for all attorneys, there is no gender differential between men and women with children. ${ }^{13}$

Finally, the coefficient on Companion Separate is not significantly different from 0 in model 5 . The coefficient on Female $\times$ Companion Separate in model 5 is negative but significant at only the 10.7 percent level, just beyond conventional statistical significance. The sum of Female and Female $\times$ Companion Separate is negative and weakly significant at the 10 percent level, which indicates that women who experience a companion-separation event have $\$ 15,988$ lower annual compensation compared with men who experience a companion-separation event. ${ }^{14}$ Limited evidence exists that family-shift-related situations may correlate with lower pay for women compared with men.

${ }^{13}$ We reestimated model 4 of Table 3 with the addition of Child $19+$ and Female $\times$ Child $19+$, treating attorneys with no children as the base category. We obtained the same qualitative results as in model 4 (unreported). The coefficients on Child 19+ and Female $\times$ Child $19+$ are not significantly different from 0 .

${ }^{14}$ We performed a number of robustness checks on the results for scienter cases and total compensation reported in the text. We looked at attorneys who experienced the birth of a child during the time period of our data set. Setting the first birth-year event as $t=0$, we compared scienter cases and total compensation for the year prior to the birth year of the first child $(t=-1)$ with 4 years after the birth $(t=4)$, covering the prekindergarten years. We have only two male and two female attorneys in our sample who experienced the birth of a child during the time period of our data set and for whom we also have data for $t=-1$ and $t=4$ (none of the attorneys had multiple births). The mean of Scienter Cases at $t=-1$ was .5 for men and 0 for women. Men had a higher number of scienter cases prior to the birth of their first child. The mean of Scienter Cases at $t=4$ was 0 for men and 0 for women. While men decreased in the number of scienter cases, the small number of observations makes it difficult to assess the general applicability of this change. The mean of Total Compensation at $t=-1$ was $\$ 150,200$ for men and $\$ 155,200$ for women. Women had higher compensation than men prior to the birth of their first child. The mean compensation at $t=$ 4 was $\$ 200,300$ for men and $\$ 198,700$ for women. By 4 years after the first birth year, women made less than men. While this trend is interesting, the small number of observations makes it difficult to assess the general applicability of this change. We also looked at attorneys who experienced a companion-separation event during the period of our data set. Setting the last year that the attorney lived in the same household with an adult companion as $t=0$, we compared scienter cases and total compensation for the 2 years prior to the event year $(t=-2)$ with 2 years after the event year $(t=$ 2 ). Because our data may only imprecisely identify the exact year of separation, we use a $[-2,2]$ window to capture the effect of separation. We have only three male and three female attorneys in our sample who experienced a companion-separation event in our data set and for whom we also have 
We also estimate attorney fixed-effects models to assess the impact of familyrelated shifts on individual attorneys, using the same variables as in models 3-5 of Table 3 (with the exception of Female), including year effects and clustering errors by attorney for each of the models. In these regressions (untabulated), the coefficients for Child at Home and Child 6-14 are positive and significant at the 5 percent and 1 percent levels, respectively. The interaction terms with Female in these models, however, are all insignificant. That is, we do not find evidence that any of our family-related shifts result in a differential change in compensation for female attorneys in the attorney fixed-effects models. ${ }^{15}$

\subsection{Who Goes?}

We next examine departure dynamics in a multivariate framework employing a Cox proportional hazard model. Our dependent variable is leaving the SEC (Left SEC) from 2004 to 2016 . The Cox proportional hazard model we estimate is as follows:

$$
h(t, \boldsymbol{X})=h_{0}(t) e^{x^{\prime} \beta}
$$

In the Cox hazard model, $h(t, X)$ is the hazard rate. The Cox model is semiparametric and does not require assumptions about the baseline hazard rate, $h_{0}(t)$. The term $\boldsymbol{X}$ represents the vector of regressors, and $\beta$ is a vector of estimated coefficients. We report the Cox models related to family characteristics in Table 4.

For model 1 of Table 4, we include a variable for the age of the attorney in the year in question (Age). Instead of Age Squared, because nearing retirement may lead to a discontinuous increase in the propensity to leave the SEC, we include an indicator variable for whether the attorney is 55 or older as of 2004 (Close to Retire). We also include the variables NLJ 250 Prior Partner, Prior Government Attorney, Top Law School, and Regional Office. We posit that partners from large law firms (Prior NLJ 250 Prior Partner) are likely coming to the SEC to burnish their credentials and are therefore less likely to stay. Attorneys in regional offices may have fewer attractive employment opportunities because they are outside the

data for $t=-2$ and $t=2$. The mean of Scienter Cases at $t=-2$ was 0 for men and 0 for women. The mean of Scienter Cases at $t=2$ was 0 for men and 0 for women. The mean of Total Compensation at $t=-2$ was $\$ 172,900$ for men and $\$ 172,800$ for women. The mean of Total Compensation at $t=2$ was $\$ 199,000$ for men and $\$ 193,200$ for women. We are unable to discern any meaningful differences in number of scienter cases or total compensation due to a companion-separation event for men and women. The small number of observations, however, makes it difficult to assess the general applicability of this finding.

${ }^{15}$ The coefficients on Female in our scienter case-assignment models in Table 2 are negative and significant, which indicates that Female corresponds to fewer scienter cases in any given year. In addition, the coefficient on Scienter Cases in Prior Year in our compensation model (model 2 in Table 3 ) is positive and significant. One explanation for why Female corresponds to lower compensation on average may be because of fewer scienter case assignments in the prior year. The negative coefficient on Female in model 2 of Table 3, even after controlling for Scienter Cases in Prior Year, may be due to fewer scienter case assignments in years before the prior year or a lower pay increase per scienter case for women compared with men. Note though that the coefficient on Female in model 2 of Table 3, while negative, is not significantly different from 0 . 
Table 4

Hazard Models for Leaving the Securities and Exchange Commission

\begin{tabular}{|c|c|c|c|c|c|}
\hline & (1) & (2) & (3) & (4) & (5) \\
\hline Age & $\begin{array}{l}-.0210^{+} \\
(-1.73)\end{array}$ & $\begin{array}{l}-.0348^{* *} \\
(-2.76)\end{array}$ & $\begin{array}{l}-.0343^{\star \star} \\
(-2.81)\end{array}$ & $\begin{array}{l}-.0355^{\star \star} \\
(-2.68)\end{array}$ & $\begin{array}{l}-.0340^{\star * x} \\
(-3.01)\end{array}$ \\
\hline Close to Retire & $\begin{array}{c}1.133^{\star} \\
(2.39)\end{array}$ & $\begin{array}{l}1.457^{\star *} \\
(3.01)\end{array}$ & $\begin{array}{l}1.557^{\star *} \\
(3.70)\end{array}$ & $\begin{array}{l}1.594^{\star *} \\
(3.66)\end{array}$ & $\begin{array}{l}1.481^{\star *} \\
(3.69)\end{array}$ \\
\hline NLJ 250 Prior Partner & $\begin{array}{l}-.014 \\
(-.03)\end{array}$ & $\begin{array}{l}.008 \\
(.02)\end{array}$ & $\begin{array}{c}.620^{*} \\
(2.05)\end{array}$ & $\begin{array}{c}.614^{*} \\
(2.02)\end{array}$ & $\begin{array}{r}.487 \\
(1.63)\end{array}$ \\
\hline Prior Government Attorney & $\begin{array}{r}.330 \\
(1.52)\end{array}$ & $\begin{array}{c}.398^{+} \\
(1.84)\end{array}$ & $\begin{array}{r}.201 \\
(.90)\end{array}$ & $\begin{array}{l}.218 \\
(.97)\end{array}$ & $\begin{array}{c}.355^{+} \\
(1.76)\end{array}$ \\
\hline Top Law School & $\begin{array}{r}-.074 \\
(-.45)\end{array}$ & $\begin{array}{r}-.084 \\
(-.51)\end{array}$ & $\begin{array}{r}.057 \\
(.35)\end{array}$ & $\begin{array}{r}.055 \\
(.34)\end{array}$ & $\begin{array}{l}.008 \\
(.05)\end{array}$ \\
\hline Regional Office & $\begin{array}{r}-.233 \\
(-1.38)\end{array}$ & $\begin{array}{r}-.200 \\
(-1.18)\end{array}$ & $\begin{array}{r}-.072 \\
(-.44)\end{array}$ & $\begin{array}{r}-.063 \\
(-.38)\end{array}$ & $\begin{array}{r}-.185 \\
(-1.21)\end{array}$ \\
\hline Female & $\begin{array}{l}-.591^{\star \star} \\
(-2.96)\end{array}$ & $\begin{array}{l}-.581^{\star \star} \\
(-2.90)\end{array}$ & $\begin{array}{r}-.365 \\
(-1.52)\end{array}$ & $\begin{array}{c}-.399^{+} \\
(-1.68)\end{array}$ & $\begin{array}{c}-.442^{\star} \\
(-2.50)\end{array}$ \\
\hline Scienter Cases in Prior Year & & $\begin{array}{c}.318^{\star} \\
(2.27)\end{array}$ & & & \\
\hline Child at Home & & & $\begin{array}{c}.396^{*} \\
(2.06)\end{array}$ & & \\
\hline Female $\times$ Child at Home & & & $\begin{array}{l}-.0967 \\
(-.25)\end{array}$ & & \\
\hline Child $\leq 5$ & & & & $\begin{array}{l}.224 \\
(.69)\end{array}$ & \\
\hline Female $\times$ Child $\leq 5$ & & & & $\begin{array}{r}-.049 \\
(-.07)\end{array}$ & \\
\hline Child 6-14 & & & & $\begin{array}{c}.516^{* *} \\
(2.58)\end{array}$ & \\
\hline Female $\times$ Child $6-14$ & & & & $\begin{array}{c}-.927^{+} \\
(-1.78)\end{array}$ & \\
\hline Child 15-18 & & & & $\begin{array}{r}-.152 \\
(-.47)\end{array}$ & \\
\hline Female $\times$ Child $15-18$ & & & & $\begin{array}{l}1.435^{\star *} \\
(2.82)\end{array}$ & \\
\hline Companion Separate & & & & & $\begin{array}{l}1.004^{\star} \\
(1.97)\end{array}$ \\
\hline Female $\times$ Companion Separate & & & & & $\begin{array}{r}-.018 \\
(-.02)\end{array}$ \\
\hline$N$ & 2,526 & 2,223 & 2,217 & 2,217 & 2,558 \\
\hline Log likelihood & $-1,140.7$ & $-1,119.8$ & $-1,180.3$ & $-1,175.3$ & $-1,386.2$ \\
\hline
\end{tabular}

Note. Results are from hazard models on attorney-year data of the departure of an attorney from the Securities and Exchange Commission as the dependent variable. Nonexponentiated coefficients are reported, with $z$-statistics in parentheses.

$$
\begin{aligned}
& +p<.10 . \\
& { }^{*} p<.05 . \\
& { }^{*} p<.01 .
\end{aligned}
$$


major financial centers. Moreover, the cost of living in those cities may be more manageable. We also include our primary variable of interest, Female, in model 1.

In model 1 of Table 4, the coefficient on Female is negative and significant at the 1 percent level. Female attorneys are 44.6 percent less likely than male attorneys to leave the SEC. To assess whether having fewer scienter case assignments in the prior year is related to the propensity of women to leave the SEC, we add Scienter Cases in Prior Year to model 1 and report the results in model 2. The coefficient on Scienter Cases in Prior Year is positive and significant at the 5 percent level. Participation in scienter cases appears to be a factor for attorneys choosing to leave the SEC. The coefficient on Female remains negative and significant (at the 1 percent level) in model $2 .{ }^{16}$

What explains the difference in propensity to leave the SEC? Women may be less likely to leave the SEC because of its attractive work environment and preferences relating to the work-family balance. To test the importance of the SEC'S work environment and work-family-related preferences in explaining the gender gap in propensity to leave the SEC, we analyze the importance of having children at home and companion separation.

We start with the Cox hazard model in model 1 of Table 4 and add the indicator variable Child at Home and the interaction term Female $\times$ Child at Home. We report the results in model 3 of Table 4.

In model 3, the coefficient on Child at Home is positive and significant at the 5 percent level. For male attorneys, having a child at home corresponds with a 48.6 percent increased likelihood of leaving the SEC compared with male attorneys without a child at home. The coefficient on Female $\times$ Child at Home is negative and not significantly different from 0 , which indicates that having a child has a similar positive correspondence with the propensity for female attorneys to leave the SEC. The sum of Female and Female $\times$ Child at Home is negative and significant at the 12.5 percent level, beyond conventional levels of significance. Thus, in this estimation we do not find evidence that women with children at home have a differential propensity to leave the SEC compared with men with children at home.

For attorneys with children at home, it is possible that the trade-offs between childcare responsibilities and financial burdens vary with a child's age. Younger children need more care, while children nearing college age are expensive. Accordingly, we also look at different age categories of children at home, including children who are 5 or younger (Child $\leq 5$ ), between six and 14 (Child 6-14), and between five and 18 (Child 5-18), substituting them in model 4 for the Child at Home variables in model 3.

In model 4 of Table 4 , the coefficient on Child 6-14 is positive and significant

${ }^{16}$ As a robustness test, we replaced the number of scienter cases for the prior year with the number of insider-trading cases for the prior year in model 2 of Table 4 . We obtain similar but not identical results to those in model 2 of Table 4 (unreported). The coefficient on Female remains negative and significant at the 1 percent level, but the coefficient on the number of insider-trading cases is not significantly different from 0 . Although participation in scienter cases is correlated with departure from the SEC, we do not find a similar correlation with participation in insider-trading cases. 
at the 1 percent level, which indicates that male attorneys are 67.5 percent more likely to leave the SEC when they live with a child between 6 and 14 years of age compared with male SEC attorneys without children at home. In contrast, Female $\times$ Child 6-14 is negative and significant at the 10 percent level, and the sum of Female and Female $\times$ Child $6-14$ is negative and significant at the 1 percent level, which indicates that having a child between 6 and 14 years of age correlates with lower likelihood of female attorneys leaving the SEC compared with male attorneys. These results make sense if one thinks that women are more likely than men to bear responsibility for the care of children. Assuming that the SEC is a relatively friendly place for the balance of work-family responsibilities, and if women take on a greater share of the family responsibilities, we should expect to see women being less likely to leave the SEC during the years when childcare responsibilities are the most demanding. The coefficient on Child 15-18 is not significantly different from 0 , which indicates that male attorneys are not more likely to leave the SEC when they have a child in high school compared with other male attorneys. In contrast, the coefficient on Female $\times$ Child $15-18$ is positive and significant at the 1 percent level, which indicates a significant difference in how having high-school-age children affects women compared with men in deciding to leave the SEC. Note also that while the coefficient on Female is negative and significant at the 10 percent level in model 4, the sum of Female and Female $\times$ Child $15-18$ is positive and significant at the 5 percent level. Women with a child in high school are more likely to leave the SEC than men. The differing pattern in propensity to leave the SEC for men and women with children of different ages is consistent with the theory that gender differences in either preferences or responsibilities regarding the work-family balance affect how men and women think about their departure from the SEC. ${ }^{17}$

The financial shock of a divorce or similar separation may also induce some attorneys to leave the SEC seeking higher pay. Therefore, in model 5 we substitute the indicator variable Companion Separate and the interaction term Female $\times$ Companion Separate. The latter variable measures the differential effect of a companion-separation event on women.

In model 5 of Table 4 the coefficient on Companion Separate is positive and significant at the 5 percent level. A companion-separation event corresponds to a 173 percent increase in the likelihood of departing the SEC, a plausible result if separations create budgetary strain. ${ }^{18}$ The coefficient on Female $\times$ Companion

${ }^{17}$ We reestimated model 4 of Table 4 with the addition of Child $19+$ and Female $\times$ Child $19+$ to model 4 , treating attorneys with no children as the base category. We obtained the same qualitative results as in model 4 (unreported) with one difference: the coefficient on Child 6-14 remains positive but now is significant at the 5 percent level. The coefficients on Child $19+$ and Female $\times$ Child $19+$ are not significantly different from 0 .

${ }^{18}$ As a robustness test, we replaced Companion Separate with an indicator variable equal to one only for the year that an adult companion stopped living in the same household and zero otherwise and an interaction term between that indicator variable and Female. The coefficient on the 1 -year alternative indicator variable is positive and significant at the 1 percent level, while the coefficient on the interaction term is not significantly different from 0 , which indicates that a companionseparation event has the similar effect of increasing the propensity to leave the SEC for both male and female attorneys. 
Table 5

Where Do They Go? Destination by Gender

\begin{tabular}{lrrrrrrrrr}
\hline & \multicolumn{2}{c}{ Male } & & \multicolumn{2}{c}{ Female } & & \multicolumn{2}{c}{ All } \\
\cline { 2 - 3 } \cline { 9 - 10 } \cline { 8 - 9 } & $N$ & $\%$ & & $N$ & $\%$ & & $N$ & $\%$ \\
\hline Private practice associate or counsel & 15 & 10.0 & & 5 & 10.6 & & 20 & 10.2 \\
Private practice partner & 54 & 36.0 & & 11 & 23.4 & & 65 & 33.0 \\
Financial or compliance industry & 45 & 30.0 & & 12 & 25.5 & & 57 & 28.9 \\
Nonprofit or academia & 3 & 2.0 & & 6 & 12.8 & & 9 & 4.6 \\
Other government & 18 & 12.0 & & 9 & 19.2 & & 27 & 13.7 \\
Retirement or nonlegal/compliance & 15 & 10.0 & & 4 & 8.5 & & 19 & 9.6 \\
$\quad$ Total & 150 & 100.0 & & 47 & 100.0 & & 197 & 100.0 \\
\hline
\end{tabular}

Note. $\chi^{2}=12.4781(\mathrm{pr}=.020)$.

Separate, however, is not significantly different from 0 . What this tells us is that a companion-separation event increases the likelihood for both men and women to leave the SEC, but we do not find a significant gender-based difference in this regard. ${ }^{19}$

\subsection{More on Selection and the Decision to Leave}

One possibility for the differential propensity for male and female attorneys to leave the SEC is a difference in post-SEC employment options available to men compared with women. Using publicly available information, we track the employment choices of the attorneys in our sample through June 2016. We collected career path information through Internet searches using the Martindale-Hubbell data set, LexisNexis, LinkedIn, and Google.

In Table 5, we break down the destination for lawyers leaving the SEC by gender. More than half of the attorneys employed by the division in 2004 were working in the private sector by 2016 . We see some patterns. The percentages of lawyers taking jobs as law firm associates are indistinguishable in gender terms, but men are more likely to take a position as a law firm partner (36.0 percent of all men who left the SEC as compared with 23.4 percent of all women who left the SEC) and marginally more likely to take a position in financial services or compliance (30.0 percent of men compared with 25.5 percent of women). Women,

\footnotetext{
${ }^{19}$ The multivariate models in Tables $2-4$ are at the attorney-year level of data. One concern is the relatively small number of observations, in particular for the interaction terms in our models. With respect to the interaction terms for children, the number of attorney-year-level observations range from a high of 139 (Female $\times$ Child $6-14$ ) to a low of 46 (Female $\times$ Child $0-5$ ) in Table 2, a high of 116 (Female $\times$ Child 6-14) to a low of 39 (Female $\times$ Child $0-5$ ) in Table 3, and a high of 144 (Female $\times$ Child 6-14) to a low of 49 (Female $\times$ Child $0-5$ ) in Table 4 . We have fewer observations for Companion Separate, with six, six, and seven observations for Female $\times$ Companion Separate in Tables 2, 3, and 4, respectively. The lack of statistically significant coefficients in particular for Female $\times$ Companion Separate in our multivariate models could be due to a lack of statistical power.
} 
on the other hand, took more nonprofit or academic positions and other government positions. ${ }^{20}$

A caveat here is that the observed positions taken after the SEC reflect not only differences in supply but also in the demand for positions by men and women. We cannot identify shifts in employment opportunities during the time period of our study that may differ for men versus women. We are therefore unable to test the causal relationship between the supply of employment opportunities and the propensity of women to leave the SEC. We nonetheless cannot reject the possibility that differences in the availability of post-SEC positions is causally related to the lower propensity of women to leave the SEC.

\section{Conclusion}

For this project, we chose an institutional setting in which prior research suggests the gender gap should be small. We found evidence of gaps in assignments and pay, with men doing better, particularly with respect to assignments. More tentatively, it may be that the differential in assignments is not the result of all women getting fewer high-quality assignments but is instead the result of a subset of women (in the middle stages of their careers) receiving or taking on fewer of these assignments. Of particular interest-given the dominant narrative in the literature that childcare responsibilities are a key driver of gender disparities - is the lack of any indication that the disparities that do exist within the SEC are driven by differences in childcare responsibilities. Our conjecture here, and it is but a hypothesis that needs a separate study to test, is that institutions can reduce the childcare-related gender disparity.

A clear difference in our findings is that men who leave the SEC are more likely to move into lucrative private-sector jobs. Women, who are less likely to move in the first place, are more likely to move to other government jobs or nonprofits. Although the SEC may be able to ameliorate the gender gap in its internal hierarchy, gender gaps creep in when there is an interaction of the internal and external markets. This article has begun to explore the effect of linkages between relatively nondiscriminatory institutions and external markets that exhibit discriminatory patterns. Our hope is that future studies will examine other government agencies, and possibly nonprofit organizations, and their connections with external private labor markets.

\footnotetext{
${ }^{20}$ We are unable to obtain post-SEC salaries for attorneys in our data set who exited the SEC, so we cannot calculate the overall gender gap in wages that results when exit options are taken into consideration. That said, on the basis of informal conversations with former SEC attorneys-who pointed out that almost no one is ever fired from the SEC and that workloads in the private sector are higher-we think it safe to assume that those who left the SEC for the private sector did so for substantially larger salaries.
} 


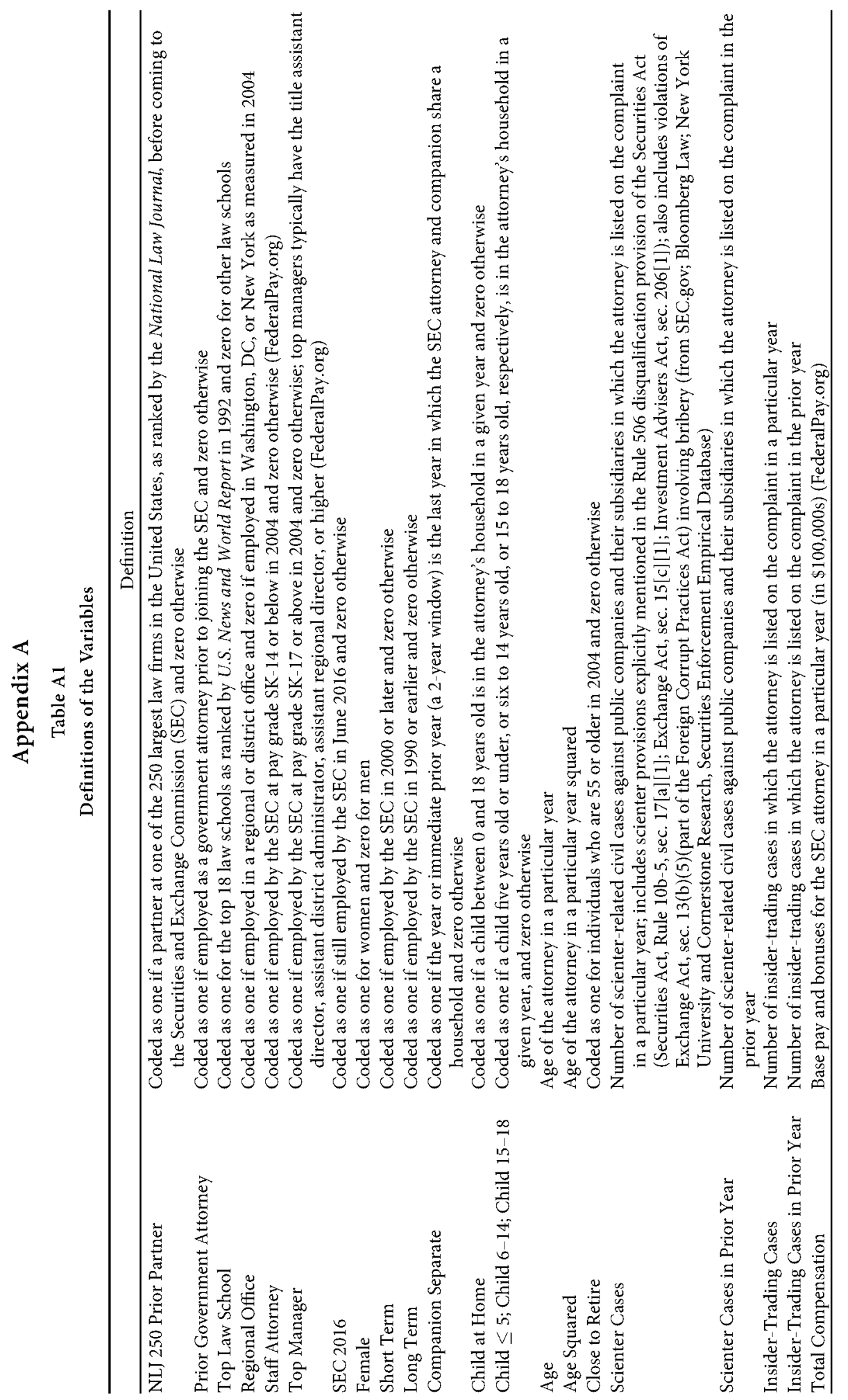




\section{Appendix B}

\section{Data Collection}

There are 3,825 individuals listed in the SEC's 2004 telephone directory. We focus on individuals either designated as "ENF" for the Division of Enforcement of the SEC (429 individuals) or as working in an SEC regional office $(2,021$ individuals). We then screened them for attorneys working either for the Division of Enforcement or in a trial or enforcement capacity in an SEC regional office, which leaves us with 542 individuals. Freedom of Information Act requests yielded job titles, pay grades, and postings through 2015. Pay-grade information is from FederalPay.org, which reports data from the Office of Personnel Management.

We developed a new methodology to gather demographic variables for the SEC attorneys in the sample. For each attorney, we determined his or her law school and college, including graduation years, from searches on Martindale-Hubbell and LinkedIn. If we were unable to determine the law school and college from the searches, we supplemented with broader Internet searches, including state bar websites. ${ }^{21}$ We then used the college and law school graduation years to develop a rough estimate of the age of the attorney (for example, we estimated age by subtracting 21 years from the college graduation year).

Using the attorney's name, SEC office location, and estimated age, we then performed a search for the attorney using a premium subscription to Whitepages in early 2018. Among the search results from Whitepages, we looked at only individuals whose age was within plus or minus 2 years of our estimated age and a location within a 90-minute commuting distance of the SEC office (as given by Google Maps using the fastest mode of transport without any traffic). If there was only one match, we moved forward with our data collection from the Whitepages match. If there was more than one match, we looked at the address history of each candidate to determine whether one more closely matched the work history of the attorney. For example, if an attorney worked in the Philadelphia office from 2004 to 2006 and then switched to the Miami office from 2007 to 2015, we would look to see if a candidate's address history included an address within commuting distance to the Philadelphia office from 2004 to 2006 and to the $\mathrm{Mi}$ ami office from 2007 to 2015 . If a candidate matched the office location history, then we treated the candidate as the SEC attorney's Whitepages match. If no candidate matched that history, then we treated the SEC attorney as having no match in Whitepages. We were able to find a match for 493 of our initial 542 SEC attorneys ( 91.0 percent of the sample).

Once we found a match on Whitepages, we collected information about age and the history of addresses for the SEC attorney over time. We also collected information about family members, including names and ages as listed on Whitepages. For each family member, we also conducted a Whitepages search to determine the history of address locations. We used the family member data to determine two types of family relationships.

\footnotetext{
${ }^{21}$ See, for an example, State Bar of California, My State Bar Profile (https://members.calbar.ca.gov).
} 
Companion. We do not rely on legal definitions of marriage at specific points in time but instead look functionally at whether two adults lived in the same household. We define a companion as any individual who is not a sibling or parent and lived in the same hou sehold as the SEC attorney and was at least 21 years old during all times there was an overlap in address. We treat an individual as a sibling of an SEC attorney if the individual and SEC attorney lived in the same household at any point in time when each was under 21 years old, and we treat an individual as a parent of the SEC attorney if the individual was over 21 years old and the SEC attorney was under 21 years old and lived in the same household at any point in time. We also treat individuals as a sibling or parent of an SEC attorney if we have some external verification of the relationship (such as through an obituary). We recorded the name and age of each companion. We also tracked both the start year of the address overlap (which may span multiple addresses) and the end year of the address overlap. If the end year is before 2018 , we treat it as the year of a companion-separation event.

Children. We define a child as a family member under 21 years old who lived in the same household as the SEC attorney. For each child, we recorded name and age.

Whitepages contains less complete information about children who are still minors. To both supplement and verify the Whitepages information, we also used Internet searches to find obituaries from 2013 onward for any family member age 70 or older (based on name and last listed location in Whitepages for the family member). Using the obituaries, we were able to determine for a subset of our sample the presence (or absence) of children for the SEC attorneys. Using this methodology, we were able to establish the presence of children for 247 of our SEC attorneys and confirm the absence of children for 27 of our SEC attorneys. To fine-tune the information further, we also did broader Internet searches, including searches on social media sites (such as Facebook), school websites, and school sport websites. These additional searches helped us in many cases to confirm the ages of the children in question. If we could only find only the grade of the child, we assumed that those in ninth grade were 14 years old and used the corresponding offset age for other grades. This secondary methodology allowed us to identify the age of at least one child for 203 of our SEC attorneys.

The quality of information from Whitepages and the obituaries is, we believe, highly accurate-particularly since we typically obtained not only the number of children and their ages but also the names of the children. In each instance in which we obtained the names of children from Whitepages and from obituaries for a particular SEC attorney, the names largely matched. The matches were not always exact. Sometimes we noticed variations in the first names such as James in one source and Jim in another source. In addition, if the obituary was published earlier than 2018, it will not contain the names of children born after its publication. Nevertheless, because our method of determining the presence of children is novel, we did an additional check for the quality of the data. We asked two of the former SEC lawyers who had been generous enough to give us comments on 
an early draft of this project to do a verification exercise. For a subset of 100 attorneys for whom we had information and whom they recalled, we compared our findings with their recall. For 10 of those 100 , they had no recall as to whether the lawyers had children. For the 90 that they did recall (88, plus the two of them), our results matched their recollection in every case.

\section{Appendix C}

\section{Abnormal Total Compensation}

As an alternate assessment of compensation patterns at the SEC for male and female attorneys based on age, we examine that portion of compensation not explained by pre-SEC characteristics. We estimate a model for Total Compensation based solely on pre-SEC characteristics of the attorneys as follows, clustering errors by attorney:

$$
\begin{aligned}
\text { Total Compensation }_{i}= & \alpha+\beta_{1 i} \text { NLJ } 250 \text { Prior Partner }_{i} \\
& +\beta_{2 i} \text { Prior Government Attorney }_{i}+\beta_{3 i} \text { Top Law School }_{i} \\
& + \text { Year Fixed Effects }+\varepsilon_{i} .
\end{aligned}
$$

We use the residuals from this regression model as our measure of the amount of total compensation that is not explained by pre-SEC characteristics (the abnormal total compensation). The mean abnormal total compensation is $\$ 894$ for men and $\$-1,769$ for women. This difference is significant at the 1 percent level $(p=.002)$. We depict the mean values for abnormal total compensation by age for male and female attorneys at the SEC in Figure C1.

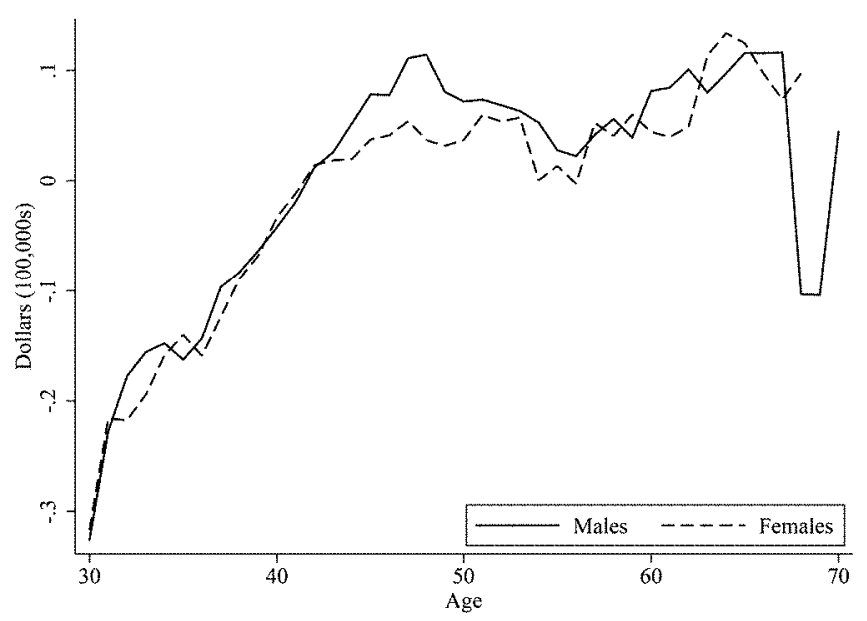

Figure C1. Mean abnormal total compensation 
Figure C1 displays a pattern for abnormal total compensation that is qualitatively similar although not identical to the one we observed for total compensation by age in Figure 2. In Figure C1, note that male SEC attorneys receive higher abnormal total compensation from their mid-40s to early 50 s, similar to Figure 2 . In Figure 2, we observed a reversal when women receive higher total compensation compared with men in their mid-50s. We do not observe the same reversal in abnormal total compensation, but the gap between men and women does narrow for abnormal total compensation in their $50 \mathrm{~s}$.

\section{References}

Altonji, Joseph G., and Rebecca M. Blank. 1999. Race and Gender in the Labor Market. Pp. 3C:3143-3259 in Handbook of Labor Economics, edited by Orley C. Ashenfelter and David C. Card. Amsterdam: North-Holland.

Azmat, Ghazala, and Rosa Ferrer. 2017. Gender Gaps in Performance: Evidence from Young Lawyers. Journal of Political Economy 125:1306-55.

Blau, Francine D., and Lawrence M. Kahn. 2017. The Gender Wage Gap: Extent, Trends, and Explanations. Journal of Economic Literature 55:789-865.

Bolton, Alexander, and John M. de Figueiredo. 2017. The Gender Wage Gap in the Public Sector. Working paper. Duke University, School of Law, Durham, NC.

Boylan, Richard T. 2005. What Do Prosecutors Maximize? Evidence from the Careers of U.S. Attorneys. American Law and Economics Review 7:379-402.

Boylan, Richard T., and Cheryl X. Long. 2005. Salaries, Plea Rates, and the Career Objectives of Federal Prosecutors. Journal of Law and Economics 48:627-51.

Chambliss, Elizabeth. 1997. Organizational Determinants of Law Firm Integration. American University Law Review 46:669-746.

Commission on Women in the Profession. 2006. Charting Our Progress: The Status of Women in the Profession Today. Chicago: American Bar Association.

- 2018. A Current Glance at Women in the Law. Chicago: American Bar Association.

Cook, Cody, Rebecca Diamond, Jonathan Hall, John A. List, and Paul Oyer. 2018. The Gender Earnings Gap in the Gig Economy: Evidence from over a Million Rideshare Drivers. Working paper. Stanford University, Graduate School of Business, Stanford, CA.

Correll, Shelley J., Stephen Benard, and In Paik. 2007. Getting a Job: Is There a Motherhood Penalty? American Journal of Sociology 112:1297-1338.

deHaan, Ed, Simi Kedia, Kevin Koh, and Shivaram Rajgopal. 2015. The Revolving Door and the SEC's Enforcement Outcomes: Initial Evidence from Civil Litigation. Journal of Accounting and Economics 60:65-96.

Dinovitzer, Ronit, Bryant G. Garth, Richard Sander, Joyce Sterling, and Gita Z. Wilder. 2004. After the JD: First Results of a National Study of Legal Careers. Washington, DC: National Association for Law Placement Foundation for Law Career Research and Education and the American Bar Foundation.

Dinovitzer, Ronit, Robert L. Nelson, Gabrile Plickert, Rebecca Sandefur, and Joyce S. Sterling. 2009. After the JD II: Second Results from a National Study of Legal Careers. Washington, DC: National Association for Law Placement Foundation for Law Career Research and Education and the American Bar Foundation. 
Dixon, Jo, and Caroll Seron. 1995. Stratification in the Legal Profession: Sex, Sector, and Salary. Law and Society Review 29:381-412.

Goddeeris, John H. 1988. Compensating Differentials and Self-Selection: An Application to Lawyers. Journal of Political Economy 96:411-28.

Goldin, Claudia. 2014. A Grand Gender Convergence: Its Last Chapter. American Economic Review 104:1091-1119.

Gorman, Elizabeth H. 2006. Work Uncertainty and the Promotion of Professional Women: The Case of Law Firm Partnership. Social Forces 85:865-90.

Gregory, Robert G., and Jeff Borland. 1999. Recent Developments in Public Sector Labor Markets. Pp. 3C:3573-3630 in Handbook of Labor Economics, edited by Orley C. Ashenfelter and David C. Card. Amsterdam: North-Holland.

Hagan, John. 1990. The Gender Stratification of Income Inequality among Lawyers. Social Forces 68:835-55.

Kay, Fiona M., Stacey L. Alarie, and Jones K. Adjei. 2016. Undermining Gender Equality: Female Attrition from Private Law Practice. Law and Society Review 50:766-801.

Kleven, Henrik, Camille Landais, and Jakob Egholt Søgaard. 2018. Children and Gender Inequality: Evidence from Denmark. Working Paper No. 24219. National Bureau of Economic Research, Cambridge, MA.

Landers, Renée M., James B. Rebitzer, and Lowell J. Taylor. 1996. Rat Race Redux: Adverse Selection in the Determination of Work Hours in Law Firms. American Economic Review 86:329-48.

Plickert, Gabriele, and Joyce Sterling. 2017. Gender Still Matters: Effects of Workplace Discrimination on Employment Schedules of Young Professionals. Laws 6:28-49.

Sauer, Robert M. 1998. Job Mobility and the Market for Lawyers. Journal of Political Economy 106:147-71.

Scharf, Stephanie A., Roberta Liebenberg, and Christine Amalfe. 2014. Report of the Eighth Annual NAWL Annual Survey on Retention and Promotion of Women in Law Firms. Chicago: National Association for Women Lawyers.

Slaughter, Anne-Marie. 2015. Unfinished Business: Women, Men, Work, Family. New York: Random House.

Sommerlad, Hilary. 2016. "A Pit to Put Women In": Professionalism, Work Intensification, Sexualisation, and Work-Life Balance in the Legal Profession in England and Wales. International Journal of the Legal Profession 23:61-82.

Sterling, Joyce S., and Nancy Reichman. 2013. Navigating the Gap: Reflections on 20 Years Researching Gender Disparities in the Legal Profession. Florida International Law Review 8:515-39.

- 2016. Overlooked and Undervalued: Women in Private Law Practice. Annual Review of Law and Social Science 12:373-93.

Sturm, Susan. 2001. Second Generation Employment Discrimination: A Structural Approach. Columbia Law Review 101:458-78.

Thornton, Margaret. 2016. Work/Life or Work/Work? Corporate Legal Practice in the Twenty-First Century. International Journal of the Legal Profession 23:13-39.

Wilkins, David B. 1999. Partners without Power? A Preliminary Look at Black Partners in Corporate Law Firms. Journal of the Institute for the Study of Legal Ethics 2(3):15-48.

Wilkins, David B., and G. Mitu Gulati. 1998. Reconceiving the Tournament of Lawyers: Tracking, Seeding, and Information Control in the Internal Labor Markets of Elite Law Firms. Virginia Law Review 84:1581-1681. 